\title{
The Current Problems of Compiling Translation - Orientated Terminological Dictionaries
}

\author{
Marina V. Trossel* \\ Siberian Federal University \\ 79 Svobodny, Krasnoyarsk, 660041, Russia
}

Received 23.06.2015, received in revised form 20.07.2015, accepted 04.08.2015

While compiling terminological translation-orientated dictionaries their authors might face with some specific problems. The present article is an attempt to analyze some of bilingual specialized dictionaries, to reveal their strong and weak features from the point of view of terminology and termnography. The author tries to give some practical advice on improving the quality of terminographic work due to the use of existing state standard specifications, international standards, recommendations of the institutions specializing in compiling dictionaries. Moreover a typical problem of every termsystemsynonymity needs some ways of solution as well.

Keywords: terminology, terminography, terminological dictionary, translation dictionary, specialized dictionary, standards, synonymity in termsystem.

DOI: $10.17516 / 1997-1370-2015-8-8-1762-1768$.

Research area: philology.

\section{Introduction}

It goes without saying that the role of dictionaries and terminological ones cannot be exaggerated. Translation-orientated dictionaries are the linkers between different languages, different cultures, they are one of the main tools of work for translators and interpreters besides the fact that they help to state the knowledge and to save it through time. It is obvious the more powerful the development of science and technology is, the greater the number of terminological dictionaries is.

Therefore the present article deals with terminography-science about theory and practice of terminological dictionaries' compiling as well as dictionaries of special lexis in certain field of science, crafts, industry or trade. The subject of this field of lexicography is scientific, industrial, trade language sub-systems, while the object is terms, terminoids, term elements, nomenclature, professionalisms, and partially professional slang words. The main functions of terminography are reference, systematizing, cultural-historic and educational. High speed of terminography development is mainly connected with practical needs of the society, because terminological dictionaries register data that are initial for technical and scientific progress, education and

(C) Siberian Federal University. All rights reserved

* Corresponding author E-mail address: marinatrossel@gmail.com 
translation work. Moreover, terminological dictionaries compose a very important part of national culture.

\section{Dictionaries and their classification}

Firstly, a few words about dictionaries. A dictionary is a reference book that includes word units organized in a certain way usually with some comments about their peculiarities of structure or function. In most cases the comments concern semantic word structure, i.e. there are word definitions and information about its usage, nevertheless there might be other comments given. It all depends on the type of dictionary, that is meanwhile connected with the following criteria: aim of dictionary, its volume, the way of word ordering, objects of description, etc. Some of the basic features might combine in one dictionary. It is worth mentioning that there is still no generally accepted typology of dictionaries, though the attempts were taken by various scientists, such as Shcherba L.V., Denisov P.N., Kemada B., Malkil Y., etc.

It is accepted to differentiate linguistic and non-linguistic dictionaries. The first ones gather and describe language lexical units, while for the second ones lexical units (terms, oneword or compound proper names) are just the starting point for presenting certain information about objects and phenomenon of non-linguistic reality. Moreover, every dictionary can be treated as general or specialized. One can label the following dictionaries as linguistic ones: glossary and translation-orientated that to some extend try to cover the lexis existing in general usage. The main aim of glossary is to denote words and give comments on their usage, to limit right and wrong forms, to connect words with language styles, to give information about grammar forms, as well as to specify spelling and reading of a word. Translation-orientated dictionaries are opposed to glossaries, as instead of meanings they present translation into certain language or languages if one deals with multi-language dictionary. As for general dictionaries, they cover all lexis but in a certain way. They may judge derivative aspects (dictionaries of word building), giving information on morphological sub-units of a word; etymological dictionaries that give information about word origin and primary motivation of a word; historical dictionaries that whether show the evolution of a word and its meaning during a certain period of time or cover some old periods of language development; dictionaries of dialects; dictionaries of frequency; spelling dictionaries; dictionaries of pronunciation. Among specialized dictionaries one may put dictionaries of idioms; dictionaries of synonyms, antonyms, foreign words; dictionaries of abbreviations; dictionaries of proper names; dictionaries of rhythms.

\section{Translation-orientated terminological dictionaries and their weak points}

The present article deals with dictionaries of special lexis or terminological dictionaries that denote reference books describing certain field of special lexis in one or some languages.

U.N. Marchuk once stated - at least one specialized dictionary is published every day in the world (Marchuk U.N. 1992). On the one hand this covers the specific areas of certain sublanguage and is to help specialists working in the field, including translators and interpreters, but on the other hand, unfortunately, they are not absolutely reliable, as in most cases the scientific level of these dictionaries is rather poor. The main problem of this has been stated by S.V.Grinev-Grinevich in his work "Introduction to terminography: How to create a dictionary" - the most part of translationorientated dictionaries are made by specialists in certain scientific or technical field having no background in lexicography (Grinev-Grinevich 
S.V. 2009). One can hardly disagree. As a result, dictionaries of the same category look different and it break such principle of terminology as adjustment.

There goes the first problem - absence of instructions, general rules and main principles of terms selection concerning the form of dictionary entry.

While analyzing some of translation dictionaries of different termsystems being published in different periods one can face with the following structure of dictionary, its entries and problems that seem obvious:

1) Russian-English Dictionary of Gymnastics, 1988: The dictionary includes 6000 words and terms, denoting terminology of such kinds of sports as: artistic and rhythmic gymnastics, acrobatics and trampolining. The author states that work of compiling was based on gymnastic terminology developed by Russian specialists of the mentioned sport field. All the terms are alphabetically ordered. The dictionary entry starts with the term and its translation. In case of having synonyms, the ones that are most widely spread are marked. The entries include information and official definition of all elements, exercises and compositions. Most of the terms denoting elements are descriptive that is typical for early period of terminology development.

2) English-Russian Traffic Dictionary, 1996: Approximate number of specialized terms in the dictionary is 10000 , covering such spheres as production, exploitation, maintenance of motor transport, traffic works, international traffic rules and warning traffic lane markings. The main part of the terms denote names of parts, assembly units and mechanisms of motor transport, tools for its maintenance, materials used in auto industry and in road cover laying. The dictionary was compiled with assistance of Danish experts. The dictionary entry can be presented by single term with its translation or term combination and translation. One of the main advantages of the work is following one of the terminography principles - monosemanticity of terms and fixation of single term in the language of translation, that is, unfortunately quite rare.

3) Russian-English and English-Russian Veterinary Dictionary, 2000: More than 5000 terms are included into the dictionary covering main notions such as processes, morphological structures typical for animals in healthy and pathologic states while different diseases, main principles of diseases, methods of prevention and diagnosing. The dictionary entry includes key term, its translation and in some cases term combinations. Some entries have synonymous terms and occasionally English brief explanation of the notion that help to understand the situation in which the term should be used properly.

4) English-Russian Dictionary of Diplomacy, 1989: One can refer the lexis of the dictionary to the following semantic groups: diplomatic activity (diplomatic service and protocol), international organizations, international relationships, economic integration, international public law, diplomatic law, current diplomatic affairs. The terms are situated due to the alphabet, the entry consists of the key term with its combinations, starting with part of speech mark. The abbreviations are partially included into the main part of the dictionary, not an appendix.

5) The Russian-English Encyclopedic Dictionary of the Arts and Artistic Crafts, 2005: The dictionary includes about 25 thousand entries on the Art (painting, sculpture, iconography, decorative and applied arts, etc.), performance (theater, cinema, TV), architecture, music, dancing, literature. Meanwhile there are terms hardly connected with the sphere of the dictionary such as: log, concrete, manteau, bloomer and so on. The entries are alphabetically ordered, in some cases they include term combinations occasionally with their meanings. The structure of the entry 
is as follows: term, its definition, translation, transcription. Some terms have marks, denoting the field of art it belongs to. On this very level there are some weak points as well: not all of the terms have definitions and transcription, despite the fact of difficulties in reading or being not widely known. Moreover the main principle of including nouns in singular is sometimes broken, e.g. aborigines, guttae, houris.

The above mentioned facts prove the weak points of terminological literature such as:

1) It is absolutely obvious that the choice of terminological units is subject-based and occasional that cannot be treated as scientific approach.

2) Terminological translation-orientated dictionaries of the same type can be different in the form of presenting information that runs counter to terminological principal of unification.

3) The system defined principle is rather vague at the level of terminological units collection, their description and analyses.

4) In case the dictionary includes semantic description of terminological units, in most cases they are sufficient and proper.

5) There are no pure and common principles of stating term combinations and units from the same terminological field.

All these weaknesses still exist in spite of fact that firstly in 1980 there was taken international State Standard "System of standards on information, librarianship and publishing. Monolingual thesaurus for information retrieval. Rules for its development, structure, composition and form of presentation" that was further interchanged in 2001 and 2002. These documents have general recommendations on collecting terms and typography of thesaurus, while there is no information about the content of thesaurus development. Besides the organizations working on compiling and editing terminological dictionaries have their own internal instructions for those who work in this field, e.g. Publishing house "Russkiy Yazyk" ("Russian Language") uses "Instructions on compiling and form presenting of Russian-foreign industry and polytechnic dictionaries". On international level there are regulatory methodological guides that were done with cooperation of ISO (International Organization for Standardization) that include information about different stages of work while compiling the dictionary. One can not mention the fact that recently there appeared a number of scientific works devoted to the problems of lexicography, terminography and problems of compiling dictionaries (Marchuk U.N., GrinevGrinevich S.V., Morkovin V.V., Baranov A.N., etc.).

The second problem that exists in terminography is also connected with standards and as follows. While compiling dictionaries not much attention is paid to international standards. In spite of the fact that there are huge number of international, state field standards in reality one faces with such situations when terminological unit in one language can have various units in the language of translation and here goes the real problem for a translator or an interpreter - how to know what unit fits the situation better, what unit is more adequate. The way out that might make the choice easier is the existence of well written definitions, but in this way the dictionaries are recommended to be created by a group of specialists both in the field of language and terminography and the one in the specialized field who is to be responsible for definitions and right choice of terms for certain situation. Therefore practical advice of compiles of Finnish-Russian Forestry Dictionary (University of Helsinki, the Department of Translation Studies) sounds appropriate - it is important to check and double-check every detail (Inkeri Vehmas-Lecto 1999). 
So probably one of the most serious problems that influence the level of translators' or interpreters' work is a considerable number of equivalents that are included to dictionary entries. It is obvious that the right choice of a term in the language of translation determines the quality of translation, therefore a lot depends on the level of translation-orientated dictionaries. It would be perfect if one notion had one translation, but in reality one faces the opposite situation. The analyses of dictionaries mentioned above show that the number of equivalents might be numerous. In some cases the authors give absolute synonyms or term variants (graphic variants, word building variants), so while choosing some form of translation the user can not be sure whether it is preferable in the language of translation. Whether it is widely used by specialists, if it is a norm or not. The situation might be even worse if partial equivalents are included into the dictionary entry as well as absolute equivalents and variants. Though the situation of synonymity is typical for every termsystem, a great work should be done while including synonymous terms and rating them in the dictionary entry not to mislead the users.

It goes without saying that the most reliable though not infallible source of information concerning terms and their meanings are standards, further parallel texts, i.e. authentic texts in the same field and on the same or similar theme in both languages. The role of work with such texts can help to get closer to the subject matter, show the collocational and syntactic relationships of different terms in texts, they can serve as the basis of concept analysis and presentation of their relationship in the form of concept systems and besides serve as the source of examples for the dictionary if necessary. Moreover, only authentic texts help to understand what terms are used by specialist of the field in everyday life and which of them are literal translations coined by lexicographers. Furthermore, for the person who is not an expert in the subject matter parallel texts are a shortcut to getting background information as the compiler of the dictionary, even despite the fact of existence of a specialist in the field nearby while working, has to know the field really well.

A few words concerning the role of experts. They are needed firstly to consult about the characteristics of concepts, secondly to help to coin new terms. They can also judge how successful the description or translation of some term is, if the semantic features are right, etc.

\section{Conclusion}

Speaking about general problem of modern terminography one should mention the fact that its theory is rather controversial. The main difficulty is the typology of terminological dictionaries. There are various approaches based on different principles. The analyse of existing classifications tells about the imperfectness of most of them and further follows that the dictionary entries look absolutely different, giving different information not always reliable making the choice of a translation unit difficult or inadequate. Therefore one of the ways out is combination of such types of dictionaries as encyclopedic, terminological and translation-orientated. Essentially as the first two types due to some terminographers are very close, as they both explain scientific and technical notions, so their dictionary entries look similar; some terminological dictionaries use elements of encyclopedic descriptions giving information about the subject of lexicographic work.

So taking everything into consideration terminographic work, in spite of numerous attempts to fix and descried different term systems and even sublanguages, needs a lot to be done on the theory of dictionaries compiling level. 


\section{Reference}

1. Azarov, A.A. Russko-angliiskii entsiklopedicheskii slovar' iskusstv i khudozhestvennykh remeesel [The Russian-English Encyclopedic Dictionary of the Arts and Artistic Crafts]. Moscow: Flinta, Nauka Publ., 2005. 816 p.

2. Belousova, A.R., Tarshis M.G. Russko-angliiskii veterenarnyi slovar'[Rusian - English Veterinary Dictionary]. Moscow, 2000. 239 p.

3. Bergenholtz, H. Manual of Specialised Lexicography. The preparation of specialised dictionaries. Amsterdam, Philadelphia. 1995. 201 p.

4. Bergenholtz, H., Kaufmann, U. Terminography and lexicography. A critical survey of dictionaries from a single specialized field. Hermes.1997. 125 p.

5. Grinev-Grinevich, S.V. Vvedenie v terminografiu: Kak prosto i legko sostavit' slovar' [Introduction to terminography: how to compile a dictionary easily]. Moscow: LIBROKOM Publ., 2009. $224 \mathrm{p}$.

6. Inkeri, Vehmas-Lecto (1999). Different Societies - Different Concepts. Difficulties in Compiling a Finnish-Russian Forestry Dictionary, Res. 74, 2: 171-177, available at http://www.issw.ch/ dienstleistungen/publikationen/pdf/3766.pdf

7. Kudashov, I.S., Kudashova S.O. (2001). Poleznye dopolneniia $k$ traditsyonnoi praktike sostavleniia perevodnykh termonologicheskikh slovarei (na primere dvukh finsko-ruskikh slovarei) [Useful extentions to traditional practice of compiling translation terminological dictionaries (on the bases of two Finnish-Russian dictionaries)], available at: http://www.dialog-21.ru/digests/dialog2008/ materials $/ \mathrm{html} / 42 . \mathrm{htm}$

8. Marchuk, U.N. Osnovy termonografii [The basis of terminography]. Moscow, 1992.75 p.

9. Moscow International Publishers in Cooperation with L\&H Publishing Co., Copenhagen Anglo-russkii dorozhno-transportnyi slovar' [English - Russian traffic Dictionary]. Moscow, 1996. $211 \mathrm{p}$.

10. Otraslevaia sistema standartizatsii. Prinzipi razrabotki normativnykh dokumentov [System of industry standardization. Principles of standart documents development] No. 7181, available at: http://www.gosthelp.ru/text/PR450297Otraslevayasistem.html

11. Sabirov, U.A. Russko-angliiskii slovar' gimnasticheskikh terminov [Russian-English Dictionary of Gymnastics]. Moscow: Russkii Iazyk Publ., 1988. 176 p.

12. Sarangova, T.A. (2013). Printsypy sostavleniia slovaria terminov Investor Relations [Principles of compiling terminological dictionary Investor Relations]. Modern Research of Social Problems, No. 5(25), available at: www.sisp.nkras.ru

13. Volkova, N. O., Geraskina N. P., Zhuravchenko K. V., Maksimova K.M., Melekh I. Y., Sukhomlina Z.I., Khorohilova V. I., Shakh-Nazarova V.S.? Shelkova T.G., Komov U.A. Anglo-russkii diplomaticheskii slovar'[English - Russian Dictionary of Diplomacy]. Moscow: Russkii Iazyk Publ., 1989,856 p. 


\section{Проблемы составления переводных \\ терминологических словарей}

М.В. Троссель

Сибирский федеральный университет Россия, 660041, Красноярск, пр. Свободныий, 79

Авторы переводных терминологических словарей сталкиваются с рядом специфических проблем. Данная статья является попыткой проанализировать ряд двуязычных терминологических словарей, выявить их преимущества и недостатки с позиции терминологии и терминографии. Автор предлагает некоторые практические советы по улучшению качества терминографической работы благодаря использованию ГОСТов, международных стандартов, рекомендаций учреждений, специилизирующихся на составлении терминологических словарей. Кроме того, в статье рассматривается такая актуальная проблема, как синонимия, которая также требует пристального внимания в теории и практике терминографии.

Ключевые слова: терминология, терминография, терминологический словарь, переводной словарь, специализированный словарь, синонимия в терминосистеме.

Научная специильность: 10.00.00 - филологические науки. 